Delft University of Technology

\title{
Observations Of Suspended Particle Size Distribution On An Energetic Ebb-Tidal Delta
}

Pearson, Stuart; van Prooijen, Bram; de Wit, Floris; Meijer-Holzhauer, H.; de Looff, A.P.; Wang, Zhengbing

$\mathrm{DOI}$

10.1142/9789811204487_0172

Publication date

2019

Document Version

Final published version

Published in

Coastal Sediments 2019

\section{Citation (APA)}

Pearson, S., van Prooijen, B., de Wit, F., Meijer-Holzhauer, H., de Looff, A. P., \& Wang, Z. (2019).

Observations Of Suspended Particle Size Distribution On An Energetic Ebb-Tidal Delta. In Coastal Sediments 2019 (pp. 1991-2003). [172] World Scientific Publishing.

https://doi.org/10.1142/9789811204487_0172

Important note

To cite this publication, please use the final published version (if applicable).

Please check the document version above. 
Green Open Access added to TU Delft Institutional Repository 'You share, we take care!' - Taverne project

\section{https://www.openaccess.nl/en/you-share-we-take-care}

Otherwise as indicated in the copyright section: the publisher is the copyright holder of this work and the author uses the Dutch legislation to make this work public. 


\title{
OBSERVATIONS OF SUSPENDED PARTICLE SIZE DISTRIBUTION ON AN ENERGETIC EBB-TIDAL DELTA
}

\author{
S.G. PEARSON ${ }^{1,2}$, B.C. VAN PROOIJEN ${ }^{1}$, F.P. DE WIT ${ }^{1}$, H. MEIJER- \\ HOLZHAUER $^{3,2}$, A.P. DE LOOFF ${ }^{4}$, Z.B. WANG ${ }^{2,1}$ \\ 1. Department of Hydraulic Engineering, Delft University of Technology, Delft, the \\ Netherlands.s.g.pearson@tudelft.nl, $\underline{\text { b.c.vanprooijen@tudelft.nl, }}$ \\ f.p.dewit@tudelft.nl \\ 2. Deltares, Delft, the Netherlands.zheng.wang@deltares.nl \\ 3. University of Twente,Enschede, the Netherlands.h.holzhauer@utwente.nl \\ 4. Rijkswaterstaat, Ministry of Infrastructure and Water Management, the \\ Netherlands.harry.de.looff@rws.nl
}

\begin{abstract}
Sustainable management of barrier islands and tidal inlet systems requires a knowledge of sediment transport pathways throughout the system. This paper places in situ suspended sediment observations (obtained using a LISST) in context with seabed sediment samples and hydrodynamic measurements to identify such pathways. The results indicate two distinct populations of sediment in suspension on the ebb-tidal delta: locally resuspended fine sand and (largely flocculated) mud exported from the Wadden Sea on ebb tide. This reinforces the notion of the strong dependence of sediment pathways on particle size. Future work will combine additional lines of evidence to better distinguish suspended sand from sand-sized flocs and provide a more robust definition of these pathways.
\end{abstract}

\section{Introduction}

Sustainable management strategies for barrier island coasts and tidal inlets require robust predictions of their morphological evolution. These systems play a key role in flood safety, navigation, fisheries, and form a living environment for numerous mammals, birds, fish, and benthic species. To predict the response of such systems to human interventions (e.g. dredging or nourishments) or sea level rise and other climate change effects, it is necessary to quantify the pathways that sediment takes as it moves through the system. Sediment transport pathways at tidal inlets are governed by complex interactions between tides, waves, wind, and density-driven forcing, and may vary significantly as a function of particle size.

The current coastal safety policy of the Netherlands hinges around maintaining sufficient sediment supplies in the coastal zone. Understanding and predicting the long-term infilling trends of the Wadden Sea and the consequent source or sink from the adjacent coastline is thus of critical importance (Wang et al., 2018). Furthermore, it is necessary to quantify this net import and export behaviour of sediment as a function of grain size. 
This paper links in situ observations of suspended sediment particle size to the composition of the seabed and concurrent hydrodynamic conditions in order to estimate sediment sources, pathways, and receptors across the Ameland Inlet system.

\section{Methodology}

From August to October 2017, an extensive field measurement campaign was carried out at Ameland Inlet in the Dutch Wadden Sea (Figure 1). Hydrodynamics, suspended sediment, and water quality were measured at 11 stations across the inlet, ebb-tidal delta, and tidal watersheds of the basin. This paper focuses on the measurements obtained by a frame located on the distal end of the ebb-tidal delta (Frame $\mathrm{F}_{\mathrm{ED}}$ ). Suspended particle measurements were contextualized with in situ measurements of hydrodynamic conditions and seabed sediment.

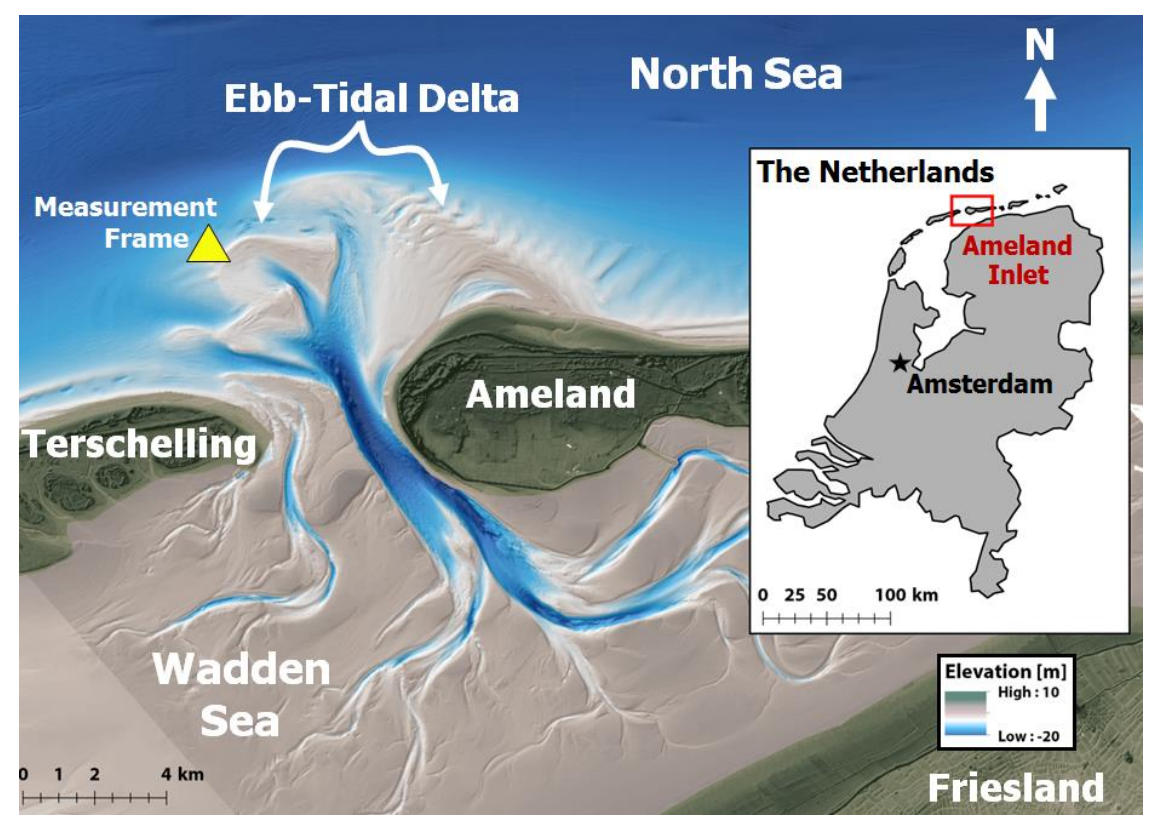

Fig. 1. Site overview of Ameland Inlet, the Netherlands. The inlet sits between the islands of Ameland and Terschelling, and connects the North Sea with the shallow Wadden Sea. The yellow triangle indicates the location of Frame $\mathrm{F}_{\mathrm{ED}}$ on the western part of the ebb-tidal delta ( $8 \mathrm{~m}$ depth). 


\section{Hydrodynamic Analysis}

Near-bed current velocities, water level, and wave heights during the monitoring period were measured using a downward-facing Nortek Aquadopp HR, a highresolution Acoustic Doppler Current Profiler (ADCP). It was mounted $0.5 \mathrm{~m}$ from the base of the frame, although actual height above the seabed varied due to field conditions. The ADCP sampled at a rate of $4 \mathrm{~Hz}$ in 30 min bursts. These measurements were first depth-averaged and then averaged over the 30 min burst intervals. Each burst was classified into four tidal stages (flood, high water slack (HWS), ebb, and low water slack (LWS)) using the velocity measurements (Figure 2). At Frame $\mathrm{F}_{\mathrm{ED}}$, the mean flood current is approximately eastward-directed, and the mean ebb current approximately westward.

\section{Bed Sediment Analysis}

In addition, 165 box cores were obtained from the seabed in order to characterize the bed sediment composition (Figure 3). To obtain a sedimentologically representative coverage of the entire ebb-tidal delta, the locations of these cores were chosen based on a series of 16 benthic habitat zones, defined by their depth, slope, orientation, and degree of recent morphological change (Holzhauer et al., in prep.). Subsamples of $8 \mathrm{~cm}$ depth were taken from the surface of the box cores and analyzed using a Malvern Mastersizer to obtain particle size distributions. This dataset was supplemented with additional samples from the Wadden Sea Sediment Atlas (Rijkswaterstaat, 1999; TNO, 2017) to provide additional context and greater spatial coverage (i.e. within the Wadden Sea).

\section{Suspended Particle Analysis}

Particle size distributions (PSD) of suspended sediment were obtained using a Laser In-Situ Scattering and Transmissometry (LISST-100X) instrument (Sequoia Scientific, 2015) mounted $0.6 \mathrm{~m}$ above the seabed on Frame $\mathrm{F}_{\mathrm{ED}}$. Differently-sized spherical particles scatter laser light in characteristic patterns across 32 detector rings, enabling the calculation of volumetric particle concentration $(\mu \mathrm{L} / \mathrm{L})$ for 32 unique particle sizes ranging logarithmically from 2.5 to $500 \mu \mathrm{m}$. Bulk particle size statistics (i.e. $\mathrm{d}_{50}$ and sorting) were calculated using the Logarithmic Folk and Ward graphical measures (Blott \& Pye, 2001).

The quality of the LISST measurements is highly dependent on the strength of the transmitted laser beam through the water column. If the optical transmission dropped beneath $10 \%$ (indicating extremely turbid water) or exceeded $99.5 \%$ 
(indicating extremely clear water), then the measurements were removed from consideration, as per Sequoia Scientific (2015). This amounted to 3\% of the time series at $\mathrm{F}_{\mathrm{ED}}$. The LISST sampled at $1 \mathrm{~Hz}$ for 15 seconds every minute; these samples were also averaged over the same 30 min intervals as the ADCP.

\section{Results}

\section{Hydrodynamic Forcing}

The tide at Ameland Inlet is semidiurnal with a spring tidal range of approximately $2.3 \mathrm{~m}$ at Frame $\mathrm{F}_{\mathrm{ED}}$ (Figure 2a). During the monitoring period, three storms were observed; two on August $31^{\text {st }}$ and September $7^{\text {th }}$ with significant wave height $H_{m 0}>1.5 \mathrm{~m}$, and the much larger Storm Sebastian on September $14^{\text {th }}$ with $H_{m 0}$ of approximately $5 \mathrm{~m}$ (Figure $2 \mathrm{~b}$ ). The storms also had a significant influence on the water level and flow velocities. For instance, a significantly longer flood period is found during Sebastian. Bed shear stress due to the combined influence of waves and currents was calculated using the method of Soulsby (1997) to give an indication of the potential for local bed material to be resuspended at Frame $F_{E D}$ (Figure 2c). The critical motion threshold for the fine sand composing much of the local sediment is exceeded during all three storms and at spring tide, which suggests that the seabed of the ebb-tidal delta is highly mobile.

\section{Bed Sediment Characteristics}

The bed of the ebb-tidal delta primarily consists of well-sorted fine sand (mean $\mathrm{d}_{50}=211 \mu \mathrm{m}$, standard deviation $\mathrm{d}_{50}=30 \mu \mathrm{m}, \mathrm{n}=165$ ), while the deeper parts of the inlet channel bed consist of medium sand (mean $\mathrm{d}_{50}=289 \mu \mathrm{m}$ ) and shell lags (Figure 3a). Mud content $(<63 \mu \mathrm{m})$ of the ebb-tidal delta areas is typically $<1 \%$ by volume, although a slightly muddier patch exists at its northeastern edge. Conversely, the mud content is up to $20 \%$ in the bed at the landward edge of the Wadden Sea and along the tidal watersheds separating Ameland Inlet from its neighbouring basins. 
(a) Water Level ( $\eta)$ \& Velocity (U, V)
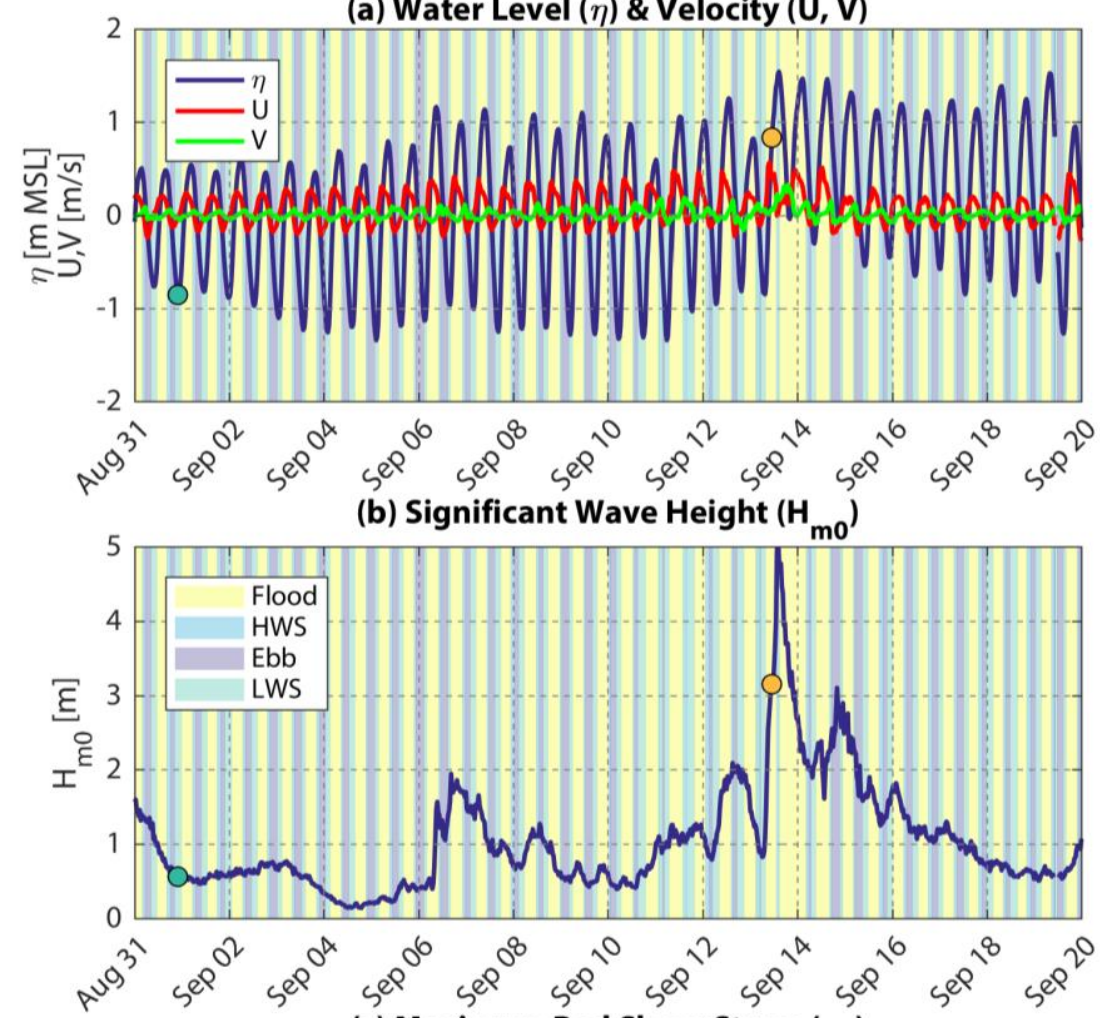

(c) Maximum Bed Shear Stress $\left(\tau_{\mathbf{b}}\right)$

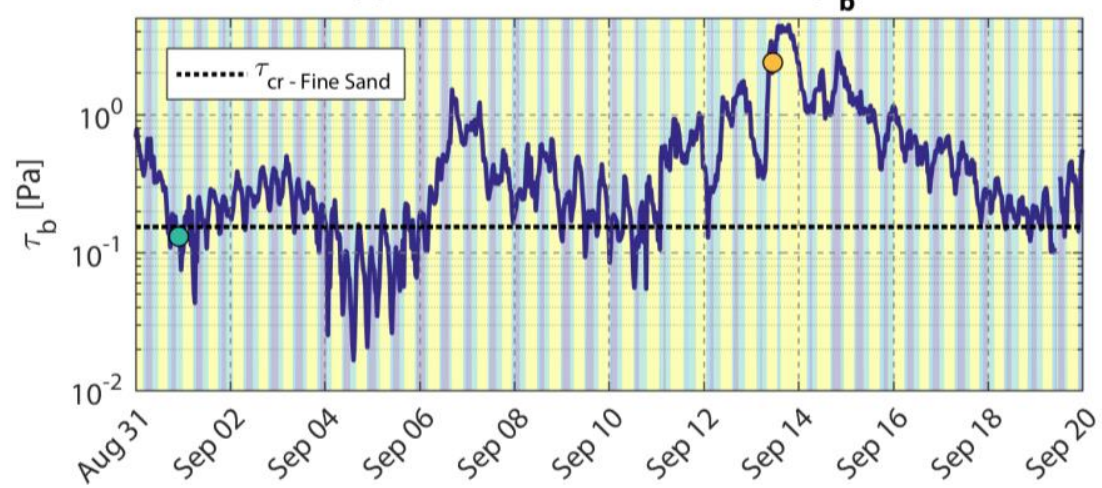

Fig. 2. In situ measurements of $30 \mathrm{~min}$ burst-averaged (a) water level $(\eta)$, near-bed velocity ( $U$ is positive eastward and $V$ is positive northward) and (b) significant wave height $\left(H_{m 0}\right)$. Vertical stripes in (a-b) correspond to stages of the tidal cycle. (c) Maximum bed shear stress under waves and currents is calculated using the method of Soulsby (1997). The dashed black line in indicates the critical bed shear stress threshold for mobility of fine sand $(125 \mu \mathrm{m})$ as calculated using Soulsby (1997). Coloured dots in (a-c) indicate sample times for S1 and S2 in Figure 4d. 

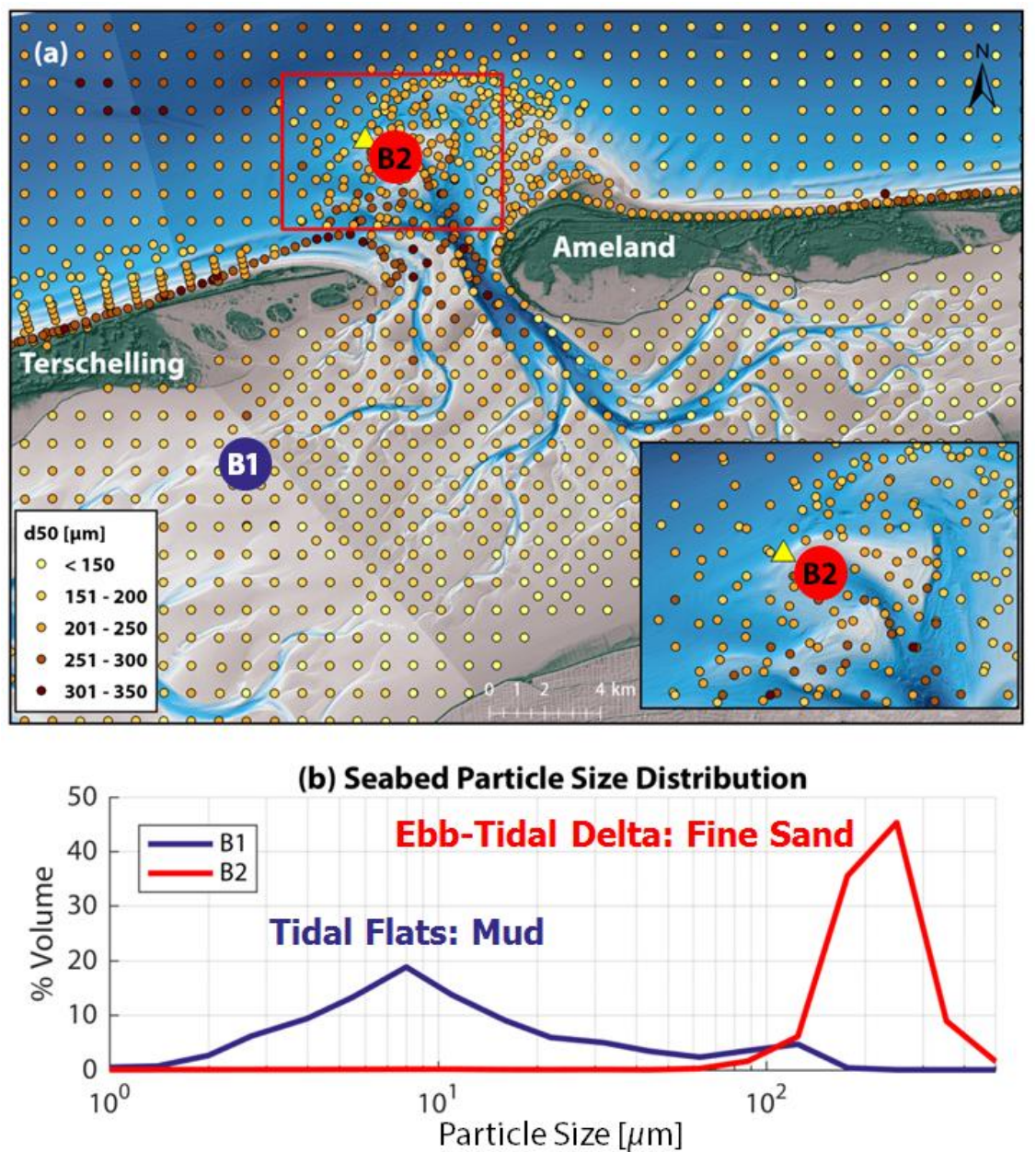

Fig. 3. (a) Median bed sediment grain size $\left(\mathrm{d}_{50}\right)$. Ebb-tidal delta sediment was obtained from box cores for this study, and basin/offshore areas were obtained from the Wadden Sea Sediment Atlas (Rijkswaterstaat, 1999). The yellow triangle indicates measurement Frame FED. (b) Particle size distribution in the bed at key locations.

\section{Suspended Sediment Characteristics}

The total volumetric suspended particle concentration measured by the LISST varies by several orders of magnitude during the measurement period, from a base level of approximately $50 \mu \mathrm{L} / \mathrm{L}$ during calmer periods to approximately $1700 \mu \mathrm{L} / \mathrm{L}$ following Storm Sebastian (Figure 4). During periods with wave heights $<1 \mathrm{~m}$, a clear semidiurnal tidal signature is visible in the concentrations. Under calm conditions at LWS, total concentrations can exceed $1000 \mu \mathrm{L} / \mathrm{L}$. 
The size of suspended sediment particles varies with ebb and flood currents, spring-neap cycles, and the impact of storms. The median suspended particle size $\left(d_{50}\right)$ typically increases towards the end of flood, suggesting a dominance of sand-sized particles. The $d_{50}$ then decreases during ebb, reaching a minimum at LWS, suggesting a greater contribution by mud-sized particles. Particles are generally best-sorted at the end of flood under calm conditions, whereas they tend to be poorly sorted after ebb or during storms.

Bed sediment closest to Frame $\mathrm{F}_{\mathrm{ED}}$ is mainly composed of fine sand $\left(d_{50}=186\right.$ $\mu \mathrm{m}$ ), and a sediment tracer study carried out on the site confirmed the transport of such sand particles in suspension across the ebb tidal delta (Pearson et al., 2018). The high concentrations of sand-sized suspended particles $(63-500 \mu \mathrm{m})$ observed by the LISST would seem to reflect this; however, many of these particles appear at times when the bed shear stress is insufficient to suspend sand particles (Figure 4a), or beyond expected settling timescales for sand. However, such particle size distributions could be explained by the additional presence of flocculated mud and organic particles advected from a remote location, rather than solely locally-resuspended sand.

Suspended sand tends to be lognormally distributed and unimodal (Sengupta (1979), whereas flocculated fine sediment and sand/silt/clay mixtures are often characterized by multimodal PSDs (Lee et al, 2012). Suspended sediment in the inlet and on the ebb-tidal delta are usually multimodal (89\% of 30 min sample bursts, $\mathrm{n}=1035$ ), with peaks suggesting a combination of fine and medium sand, silt and clay particles (e.g. Figure 4d). Changes in the median particle size and sorting reflect the hydrodynamic forcing, but the multimodal nature of the PSDs mean that these statistics alone are insufficient to describe sediment dynamics on Ameland ebb-tidal delta.

Flocs can be distinguished by examining concurrent hydrodynamic measurements. High-concentration bursts of sediment (e.g. S1 in Figure 4d) frequently coincide with calm conditions at LWS. This suggests that the fine sediment has been ejected from the Wadden Sea during ebb tide past Frame $\mathrm{F}_{\mathrm{ED}}$ (e.g. Figure 5). Conversely, PSDs corresponding to flood tide and under high waves are more likely to contain higher proportions of sand (e.g. S2 in Figure 4d). Thus, there are two distinct populations of sediment in suspension on Ameland ebb-tidal delta: locally-resuspended sand, and mud originating from within the Wadden Sea. Both may be present simultaneously, but the dominance of a particular type depends on the hydrodynamic conditions. 
(a) LISST Concentration

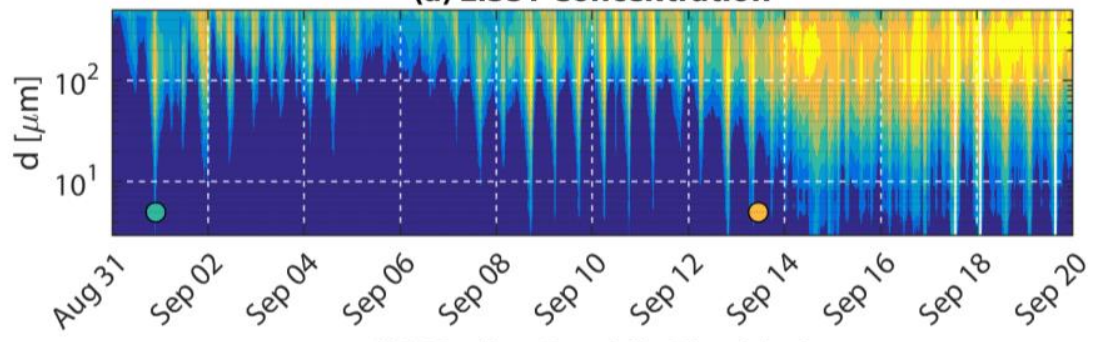

(b) Median Particle Size $\left(\mathbf{d}_{50}\right)$

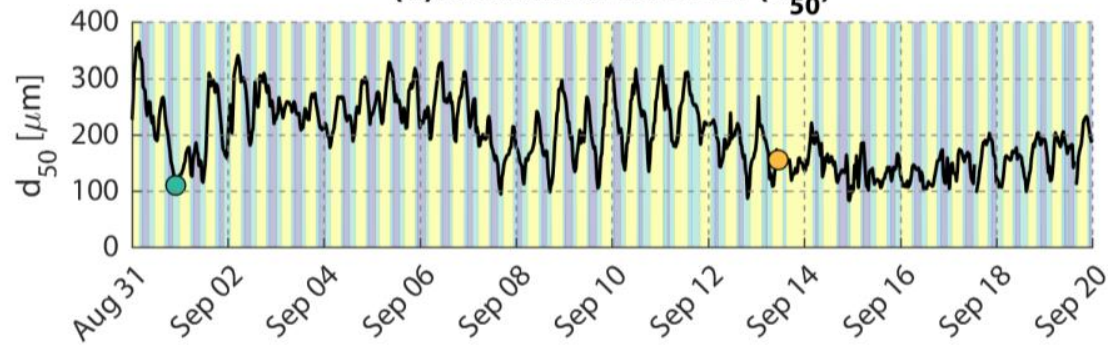

(c) Sorting

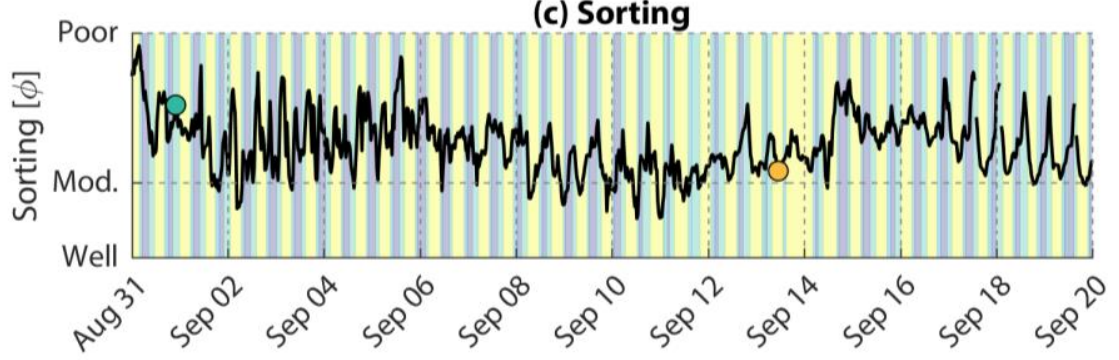

(d) Example Suspended Particle Size Distributions

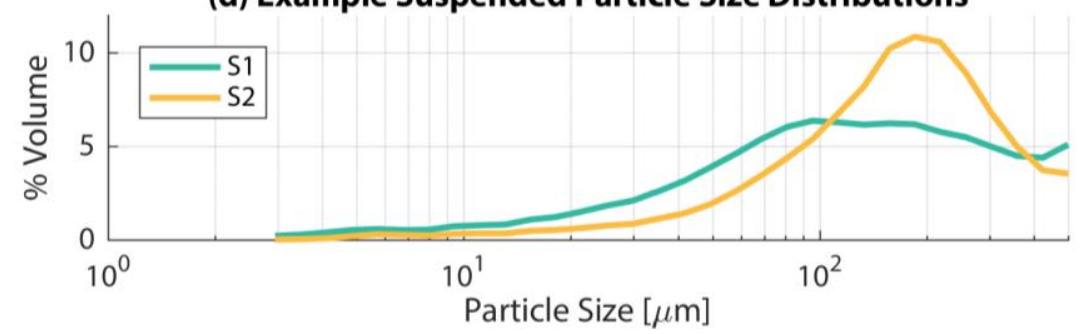

Fig. 4. In situ measurements of (a) suspended particle size distribution and concentration measured using LISST at Frame $\mathrm{F}_{\mathrm{ED}}$. (b) Median particle size $\left(\mathrm{d}_{50}\right)$ and (c) sorting coefficient (standard deviation) from 0.5 (well-sorted) to 2.0 (poor) using the Logarithmic Folk and Ward graphical measures (Blott \& Pye, 2001). Vertical stripes in (b-c) correspond to stages of tidal cycle, see

Figure 3 for legend. (d) Example particle size distributions at key moments. Coloured dots in (a-c) indicate sample times for S1 and S2 in (d) 


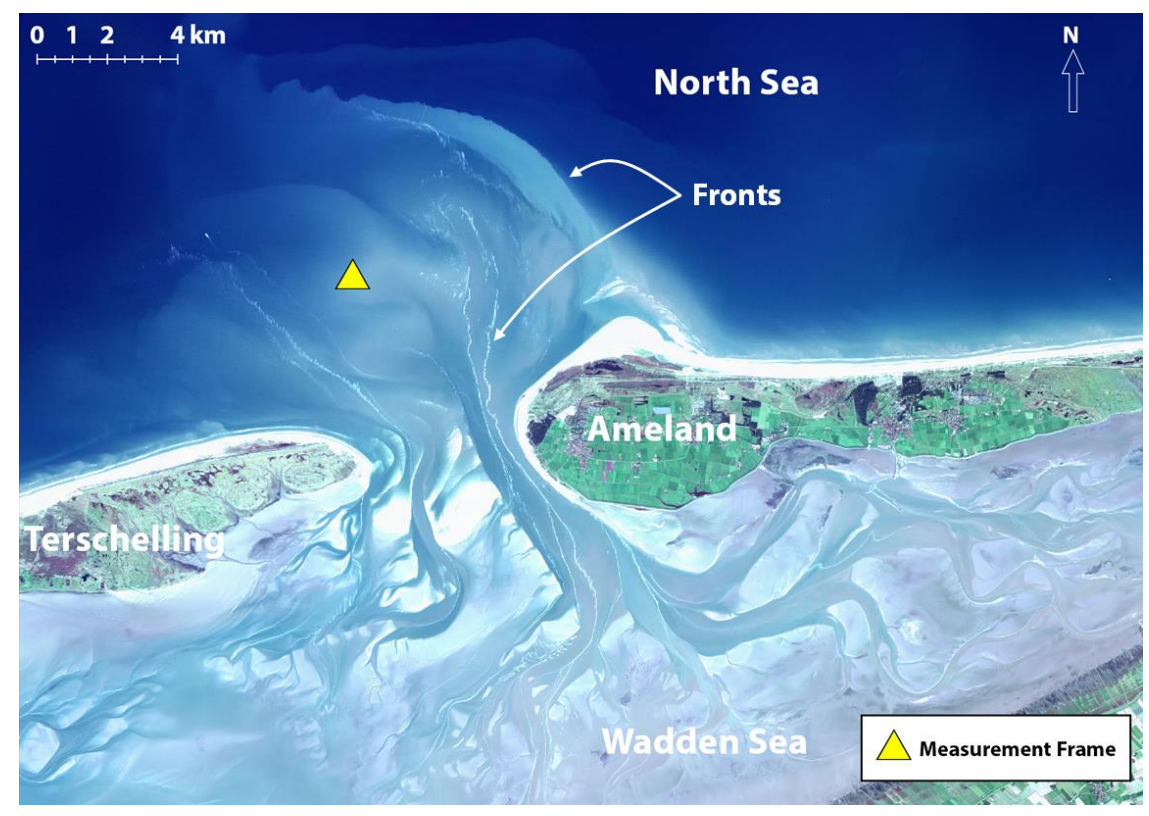

Fig. 5. Satellite image of Ameland Inlet on October $15^{\text {th }}, 2017$ (outside measurement period). Taken towards the end of low water slack (10:40am), a highly turbid plume of suspended matter is ejected from the Wadden Sea, across the ebb-tidal delta and several km into the North Sea. Fronts are visible as white lines of foam and zones with sharp colour contrast. Sentinel-2 image courtesy of Discussion satellietbeeld.nl: @ NEO B.V. Amersfoort, () ESA 2015-2018.

There are two distinct populations of sediment in suspension on Ameland ebbtidal delta, and their presence depends on the hydrodynamic conditions. Locally resuspended sand at flood tide reflects the predominantly fine sand of the ebbtidal delta, whereas the presence of flocculated mud at ebb and LWS reflects the Wadden Sea's much higher mud content. This reinforces the notion of different pathways and connectivity as a function of grain size. This study uses a unique set of field observations of suspended sediment transport on an energetic ebbtidal delta in a mixed sediment environment. These findings demonstrate the challenge of measuring and interpreting suspended sediment mixed sand/mud environments.

Although we can derive detailed PSDs from the LISST data, the simultaneous presence of both sand and sand-sized flocs makes it impossible to confidently describe sand and mud transport using the LISST alone. Furthermore, a spherical particle inversion method was used to interpret the LISST results, and the anisotropy of flocs or other suspended organic matter may influence the 
measured PSDs. Furthermore, the LISST's accuracy may be affected by variations in particle composition (e.g. solid grains of sand vs. flocs),

The measurements used in this study are limited in their scope, both temporally and spatially. The 21 day period captured here encompasses a full spring-neap tidal cycle with a mix of calm and stormy conditions (including the largest storm of 2017), but do not capture seasonal variations which may affect suspended organic matter. Furthermore, Frame $F_{E D}$ measured a single point in a highly dynamic area, and as such may not be completely representative of the entire ebb-tidal delta. In addition, the results from this study can be used to calibrate and validate a multi-fraction sediment transport model and extend the analysis over larger spatial extents and periods of time.

\section{Outlook}

To increase confidence in the classification of suspended sediment, additional support is required. Ambiguity in the composition of sand-sized particles may be resolved by analyzing the differential response of acoustic and optical signals from ADCP and OBS measurements on the ebb-tidal delta as per Fugate \& Friedrichs (2002). Multimodal PSDs can also be broken down into constituent distributions using Gaussian Mixture Models (e.g. Lee et al, 2012), and measured chlorophyll levels can be used to estimate the effect of suspended organic matter on flocculation (e.g. Shen et al., 2018).

Antecedent wind conditions may also be a predictor for high mud concentrations on the ebb tidal delta, if mud is resuspended from intertidal areas in the Wadden Sea by wind-driven waves and currents, then discharged on the ebb tide. For instance, the turbid plume captured in Figure 5 was preceded by 5 days of persistent wind from S/SW directions (KNMI, 2018). Such trends in local versus remote sources of suspended sediment may also be revealed by examining hysteresis behaviour of sediment concentrations (e.g. Jalón-Rojas et al., 2015).

Data collected from other instruments located around Ameland Inlet during the field campaign should be used in the interpretation of the particle size distributions to provide greater spatial context for the behaviour observed at Frame $\mathrm{F}_{\mathrm{ED}}$. The results of a sediment tracer study carried out on the ebb-tidal delta (Pearson et al., 2018) can also be incorporated to shed light on the transport of sand particles there.

The last step will be to examine these measurements in the context of a numerical model. This allows us to expand the scope of the present study from 
limited observations at a single point to larger spatial and temporal scales. The suspended particle size distribution data obtained here can also be used to improve the schematization of sediment in multi-fraction numerical models. By combining additional lines of evidence, we will obtain a more robust description of sediment pathways in Ameland Inlet.

\section{Conclusions}

Suspended particles on Ameland ebb-tidal delta are mainly fine sediment and flocs during calm conditions, but locally resuspended sand dominates during more energetic conditions. The western part of the ebb tidal delta functions as a source, pathway, and receptor for fine sand, but merely as a pathway for mud. Although there are large quantities of mud in suspension, they do not persist in the seabed there. The results suggest a variation in sediment connectivity between the ebb-tidal delta and other sources or receptors in the Ameland system as a function of grain size and hydrodynamic forcing.

These findings are essential for the development of numerical models with multiple sediment fractions, for predicting the evolution of nearby sand nourishments, and for the description of ecological habitats. Future research will focus on integrating additional measurements into the present analysis, numerical modelling of sediment transport in Ameland Inlet, and predicting the potential effects of nourishments and climate change on sediment pathways there.

\section{Acknowledgements}

This work is part of the research programme 'Collaboration Program Water' with project number 14489 (SEAWAD), which is (partly) financed by NWO Domain Applied and Engineering Sciences. Special thanks to the Dutch Ministry of Infrastructure and Water Management (Rijkswaterstaat and Rijksrederij) for organizing the field campaign and for their ongoing support as part of the Kustgenese 2.0 project. Thanks also to Rieneke van Noort, Erik Hendriks, Ad Reniers, Marion Tissier, Alejandra Gijón, Claire Chassagne, and Romaric Verney for their fruitful discussions.

\section{References}

Blott, S. J., \& Pye, K. (2001). GRADISTAT: a grain size distribution and statistics package for the analysis of unconsolidated sediments. Earth Surface Processes and Landforms, 26(11), 1237-1248.

Compton, T. J., J. Van der Meer, S. Holthuijsen, A. Dekinga, J. Horn, and L. 
Klunder (2013), Synoptic Intertidal Benthic Surveys Across the Dutch Wadden Sea 2008 to 2011.

Fugate, D. C., \& Friedrichs, C. T. (2002). Determining concentration and fall velocity of estuarine particle populations using ADV, OBS and LISST. Continental Shelf Research, 22(11-13), 1867-1886.

Gartner, J. W., Cheng, R. T., Wang, P. F., and Richter, K. (2001). Laboratory and field evaluations of the LISST-100 instrument for suspended particle size determinations. Marine Geology, 175:199-219.

Jalón-Rojas, I., Schmidt, S., \& Sottolichio, A. (2015). Turbidity in the fluvial Gironde Estuary (southwest France) based on 10-year continuous monitoring: sensitivity to hydrological conditions. Hydrology and Earth System Sciences, 19(6), 2805-2819.

KNMI (2019). Klimatologie: Daggegevens van het weer in Nederland. Royal Netherlands Meteorological Institute (KNMI). Available from: http://projects.knmi.nl/klimatologie/daggegevens/selectie.cgi. (Accessed 17 January 2019).

Lee, B. J., Fettweis, M., Toorman, E., \& Molz, F. J. (2012). Multimodality of a particle size distribution of cohesive suspended particulate matters in a coastal zone. Journal of Geophysical Research: Oceans, 117(C3).

Leopold, M. F., and M. J. Baptist (2016), De buitengewone biologie van de buitendelta's van de Nederlandse Waddenzee, Den Helder, Netherlands.

McDougall, T.J. and P.M. Barker, 2011: Getting started with TEOS-10 and the Gibbs Seawater (GSW) Oceanographic Toolbox, 28pp., SCOR/IAPSO WG127, ISBN 978-0-646-55621-5.

Pearson, S., van Prooijen, B., Poleykett, J., Wright, M., Black, K., \& Wang, Z B. (2018). Monitoring sediment transport patterns on an energetic ebbtidal delta using dual-signature tracers. Poster presentation at American Geophysical Union 2019, Washington, DC. DOI: 10.1002/essoar.10500094.1

Rijkswaterstaat (1999), Sedimentatlas Waddenzee, 36-38.

Sengupta, S. (1979). Grain-size distribution of suspended load in relation to bed materials and flow velocity. Sedimentology, 26(1), 63-82.

Sequoia Scientific (2015). LISST-100X Particle Size Analyzer User's Manual Version 5.1, Bellevue, WA: Sequoia Scientific, Inc.

Shen, X., Toorman, E. A., Lee, B. J., \& Fettweis, M. (2018). Biophysical flocculation of suspended particulate matters in Belgian coastal zones. Journal of Hydrology, 567, 238-252.

Soulsby, R. (1997). Dynamics of Marine Sands: A Manual for Practical Applications. Thomas Telford.

TNO (2017), DINOloket: Ondergrondgegevens bekijken en aanvragen, Available from: https://www.dinoloket.nl/ondergrondgegevens (Accessed 13 June 2017) 
Wang, Z. B., E. P. L. Elias, A. J. F. van der Spek, and Q. J. Lodder (2018), Sediment budget and morphological development of the Dutch Wadden Sea: impact of accelerated sea-level rise and subsidence until 2100 , Netherlands J. Geosci., 97(3), 183-214, doi:10.1017/njg.2018.8.

YSI Incorporated, 2012. 6-Series Multiparameter Water Quality Sondes User Manual Revision J., Yellow Springs, Ohio: YSI Incorporated. 